\title{
'THE PHARMACOLOGY OF THE INSECT HEART
}

I. The action of Adrenalin and Acetylcholine on the heart of the Water-bug (Lethoceros)

\author{
Erasmo G. Mendes \\ (Dept. of General and Animal Physiology, \\ University of São Paulo, Brazil).
}

\section{INTRODUCTION}

The present state of the pharmacology of the Insect heart is u1 satisfactory, as BEARD (1953, p. 263) recently pointed out. The problem, according to this author, has been investigated in the intact or in the isolated heart and drugs have been tested at randon or without respect to their modes of action on other systems and there is no reason to believe that the response to drugs is the same in all Insects. Yet, he complains, comparative studies are few and generalizations accordingly cannot be safely made. What is known is the result of two approaches, one with the purpose of explaining normal heart action through the use of drugs having a known action on other animals, the other involving the use of the heart and circulatory responses as a criterion of mode of action of compcunds having insecticidal value.

During the course of the class-room work in our Department, with the puipose of showing the heart beat of an Insect, a large water-bug of the genus Lethoceros was once dissected and proved to he an excellent material for that kind of study. Even after this first and perhaps not too careful exposure of the heart, the organ immediately resumed its beating and in such a way that I was soon led to record in situ the heart beat with the procedure commonly usea in the case of the frog heart. The recording was in ali respect satisfactory, and therefore the heart of the water bug was chosen for a series of studies of the response of the organ to drugs. In this first paper, the results obtained with adrenalin and 
acetyleholine, after preliminary observations on the $\mathrm{pH}$ and the saline, are reported.

The action of Adrenalin upon the insect heart was studied by DAVENPORT (1949) in Sienopelmatus and he reported that the drug at $10 .^{6}$ retards and at higher concentrations arrests the o: gan. KRIJGSMANN \& KRIJGSMANN (1950), on the contrary, found out that adrenalin stimulates the isolated heart of Periplaneta. Acetylcholine was found to accelerate the heart rate of Molanoplus (HAMILTON 1939), Blatta (PROSSER 1942), Apis (PROSSER. 1. ci.,), Stenopelmatus (DAVENPORT, 1. c.) and Periplaneta (KRIJGSMANN \& KRIJGSMANN, 1. c.). HAMILTON (1. c.) in Melanoplus observed immediate stimulation with acetylcholine, but also irregularities due to the development of slow rhythmic contractions of the allary muscles. Isolated segments of the heart, however, showed similar types of response and this would indicate that $\mathrm{ACh}$ does not act upon a single localized center. DAVENPORT (1. c.) in Stenopelmatus found that sensitive heart preparations can be stimulated even with $10-{ }^{6} \mathrm{ACh}$ and that pric treatment with physostigmine makes less sensitive preparations also sensitive to $10-{ }^{6} \mathrm{ACh}$. Higher concentrations produced a marked accelerarion in rate, increased the tonicity and induced a transitory systolic tetany. ACh would also restore some activity in fatigued or depressed hearts. Other choline derivatives have also been tested. Acetyl-beta-methylcholine, although less effective than ACh, also stimulates the heart of Stenopelmatus. Carbaminoylcholine may induce a systolic tetany similar to that caused by ACh. In view of some cholinesterasic activity of Melanoplus hea:t extracts (MEANS 1942) and of the fact that physostigmine potentiates the action of $\mathrm{ACh}$ in Stenopelmatus, DAVENPORT (1. c.) suggested that the heart action in insects might represent a cho!inergic system.

\section{MATERIAL AND METHODS}

Mostly large representatives of the genus Lethoceros, measuring from 6 to $9 \mathrm{~cm}$ in length were employed in the experiments. In some cases specimens belonging to the genus Belostoma were also used. The animals, captured in the surroundings of S. Paulo, were 
kept in the laboratory in large crystallizers containing pond or simp'y tap water. In the experiments, the first step consisted in severitg the sting and legs at their basis, after previously sectioning it.e nerve cord in the region between the head and the thorax, behind the subesophagical ganglion. An incision followed separating the abdominal sternites from the tergites. The animal was then pinned down on its backs to a wax tray and the strip of sternum: digestive tract and gonad were carefully lifted away, exposing ti $\varepsilon$ dorsal vessel. The preparation from then on was continuously bathed with fresh saline, the wax tray being clamped at an angle so that the perfusion fluid flowed gently over the heart in a posteroanterior direction. Only those preparations which after períusing with saline for some minutes exhibited a regular heart keat were used in the experiments. In the case of Lethoceros, to record the beatings a delicate hook to which a long thread of woman's hair was attached was carefully cramped on the wall of the dorsal vessel and the cpposite end of the thread connected with a long (ca. $20 \mathrm{~cm}$ ) and light aluminium lever. This finally inscribed the beatings on a smoked drum of a kymograph. In the case of Belostoma, much smaller in size, the heart rate was checked visually with a stopwatch. Drugs were administered directly to the heart from a pipette, after stopping the continuous flow of saline, and in such a quantity that the remaining traces of plain saline surrounciing the heart were completely flushed away and replaced by the drug solution. Acetylcholine chloride from Roche Products Co. and adrunain chloride from Parke, Davis and Co. were used. The former was dissolved in saline from the solid state and the latter diluted frem $10^{3}$ aqueous solution contained in the ampules.

\section{RESULTS}

a. The saline and the $p H$. The physiological saline according to WILDER AND SMITH (1938) was used. Its composition is the following: $\mathrm{NaCl}, 5.5 \mathrm{gm} ; \mathrm{KCl}, 0.14 \mathrm{gm} ; \mathrm{CaCl}_{2}, 0.12$ $\mathrm{gm}$ an $\mathrm{g}^{-1}$ distiled water to a liter, with a $\mathrm{pH}$ of 5.5 Acetylcholine dissclved in this unbuffered saline increased the $\mathrm{pH}$, which at $10^{7}$ was 5.9, at $10^{-}$6.2, at $10^{5} 6.2$ and at $10-^{4}$ 6.3. Adrenalin, on the contrary, decreased the $\mathrm{pH}$, which at $10^{4}$ was 3.7 , but regularly 
increased with further dilutions. In some experiments, the pH of WIL DER AND SMITH's saline was adjusted to 7.3 with $\mathrm{M} / 2 \mathrm{Na}_{2} \mathrm{HPO}_{4}$, but, as a rule, unbuffered saline was used, since it proved to be more efficacious in restoring the beat of hearts arrested in consequence of traumas or after drug test which caused depression or arrest of the organ. Tracing n. 5 of fig. 3 shows the ability of unbuffered WILDER AND SMITH's saline in restoring the heart beat after severe administration of $\mathrm{ACh}$. Since the $\mathrm{pH}$ of this unbeffered saline is $\mathbf{5 . 5}$, the suggestion is made that the optimal $\mathrm{pH}$ for Lethoceros heart is on the acid side of the neutral point.

Another insect saline which was used by YEAGER (1939) in the roach heart and blocd and composed of: $\mathrm{NaCl}, 10.93$ $\mathrm{gm} ; \mathrm{KCl}, 1.57 \mathrm{gm} ; \mathrm{CaCl}_{2}, 0.85 \mathrm{gm}$ and $\mathrm{MgCl}_{2}, 0.17 \mathrm{gm}$, was also tested. This saline caused an immediate stop of the heart beat, which was promptly washed out with WILDER AND SMITH's saline. Even when deprived of $\mathrm{MgCl}_{2}$, the YEAGER's saline could not be used as shown in the tracirg 1 of fig. 1. Tracing 2 of fig. 1 shows the artion of a saline used in the heart of the Brazilian fresh-

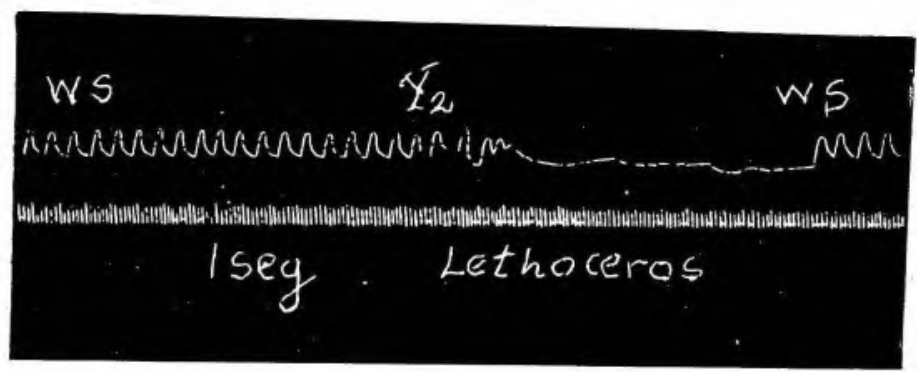

Tracing 1: The effect of YEAGERS's saline deprived of $\mathrm{Mg}_{\mathrm{g}}\left(\mathrm{Y}_{2}\right)$ on the heart of the waterbug previously bathed with WILDER \& SMITH's saline (WS).

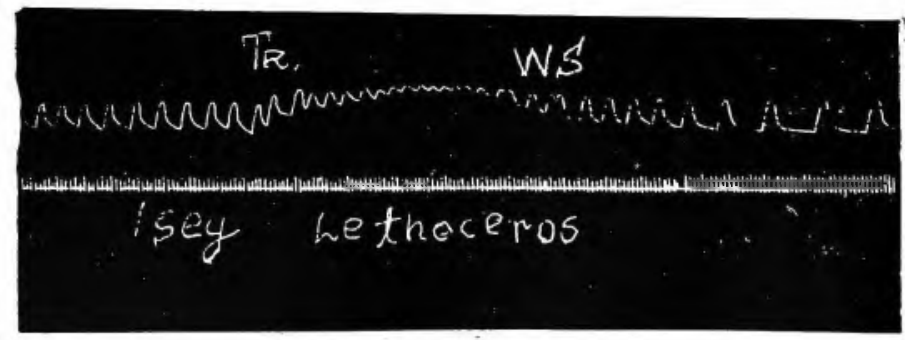

Tracing 2: The cffect of a saline (for the Brazilian fresh water crab Trichodactylus, Tr) with less $\mathrm{Na}$ than WILDER \& SMITH's on the heart of the water bug. 
water crab Trichodactylus (VALENTE, in the press), with a low concentration of $\mathrm{NaCl}$.

b. The action of adrenalin. Fig. 2 shows four tracings recorded in situ of the heart of Lethoceros under the action of different corcentrations of adrenalin. It can be clearly seen that with $10^{7}$ and $10^{6}$ there is stimulation of the heart beat, the frequency principally being increased. With $10^{5}$ a tendency to systolic tetany appears and with $10^{4}$ this systolic tetany becomes almost complete.

Similar results were obtained with Belostoma, the pronounced tendency to systolic tetany being always present with $10^{5}$ and $10-4$ Ad.

c. The action of acetylcholine. Fig. 3 shows five tracings recorded in situ of the heart beat of Lethoceros urider the action of acetylcholine solutions from $10-^{6}$ to $10-^{2}$. The tracings indicate that with $10-^{6}$ there were no changes in frequency, although the amplitude seems to be slightly increased. This increase in amplitude, however, can be considered as a mere hydrostatic effect, since there was an interval between the removal of plain saline and administration of the drug, during which the organ remained wet, but not under liquid pressure. This hydrostatic pressure can clearly be seen in the displacing of the base line of the tracings. With $10-^{5}, 10-^{4}$ and $10-^{3}$ the situation was not significantly different and one could hardly speak of essential modifications in the frequency $10^{2} \mathrm{ACh}$ was tested to find out just how far could the water bug heart remain indifferent to the drug. An immediate diastolic block was then cbserved, which was, hcwever, promptly reversible on washing with saline.

The tracings of the figures refer to experiments performed with unbuffered saline. In those using buffered saline, similar results were obtained. As to Belostoma, the results were not so uniform, in a few cases a little stimulatory effect of ACh seeming to be present and in a few cthers depressory effects being observed. As a rule, however, no effect at all was observed.

d. The cholitiesterase activity of the water bug heart. The cholinesterase activity of extracts of Belostcma's and Lethoceros' hearts was checkeci according to the technique of AMIMON (1934). 


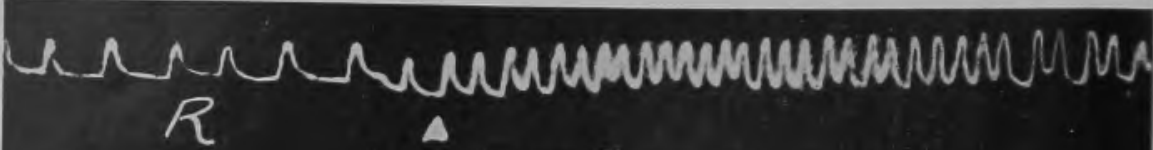

$$
\begin{aligned}
& \text { Ad } 10^{-7} \\
& 1 \text { sec Lethoceros }
\end{aligned}
$$

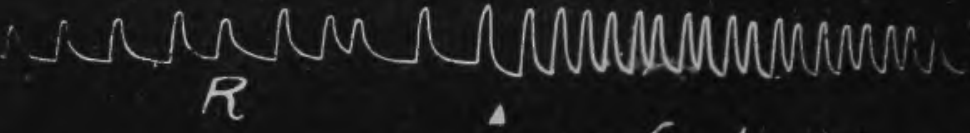

$$
\begin{aligned}
& \text { Ad } 10^{-6} \text { Lethoceros }
\end{aligned}
$$

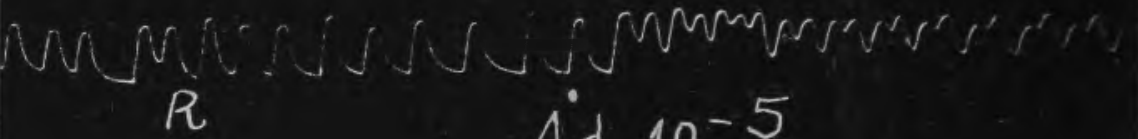

$$
\begin{aligned}
& R \quad \dot{A d} 10^{-5} \\
& 1 \mathrm{sec} . \\
& \text { Lethoceros }
\end{aligned}
$$

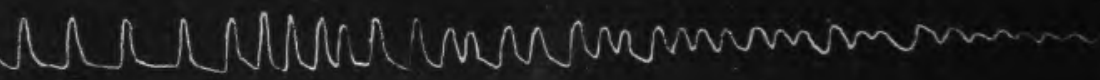

$$
\begin{gathered}
R \text { Ad } 10^{-4} \text { Lethoceros } \\
1 \mathrm{sec} .
\end{gathered}
$$

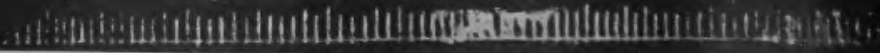




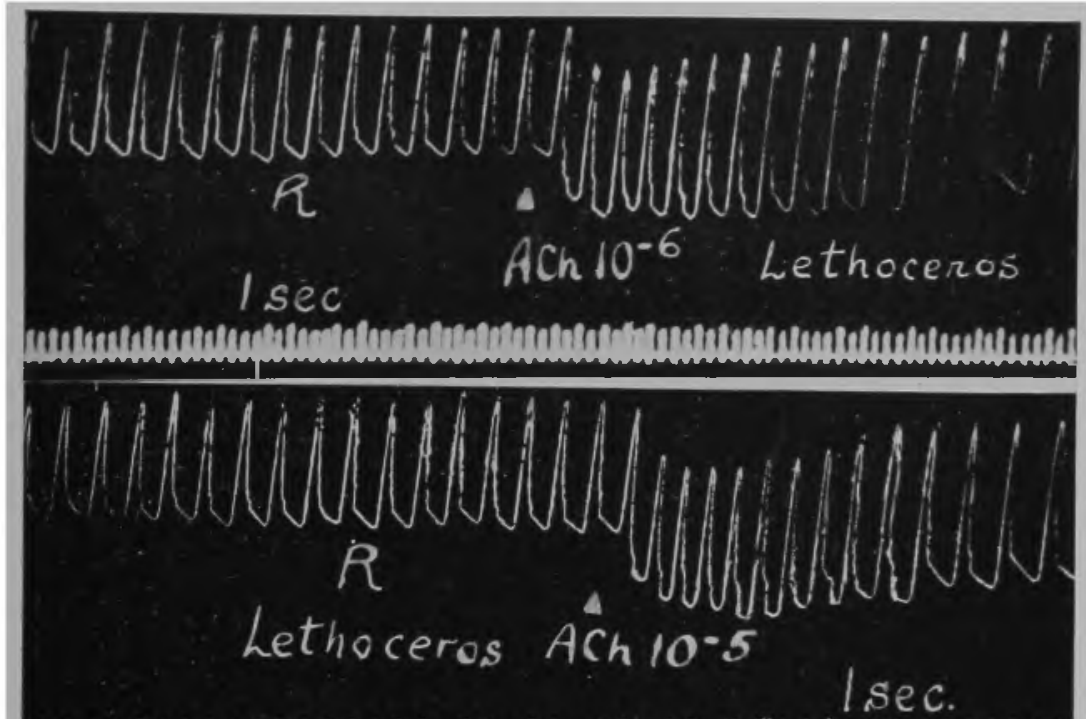

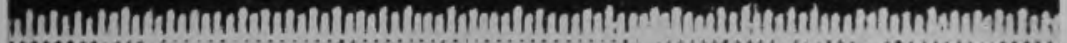

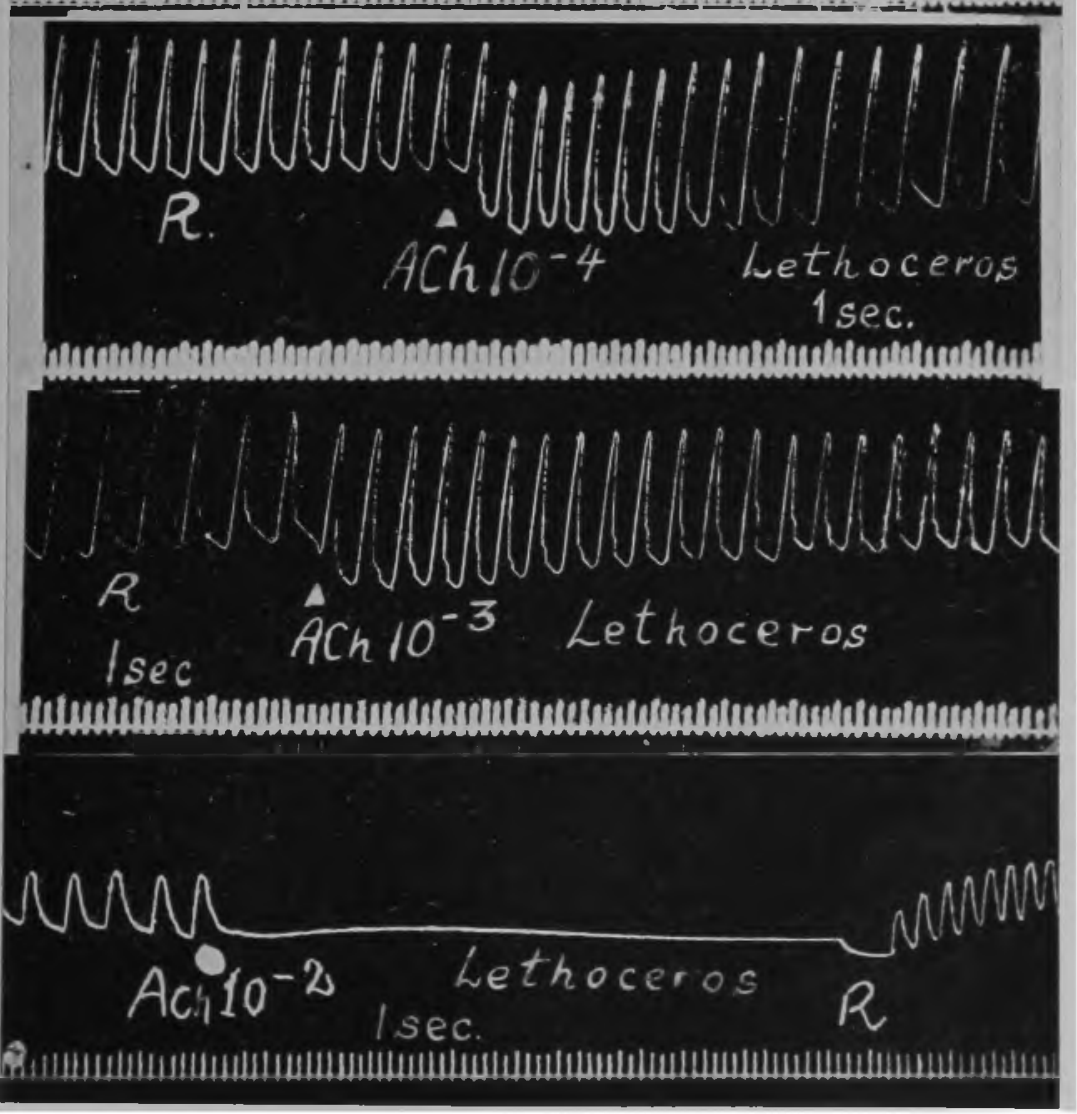

Figura 3 
Extracts of $0.5 \mathrm{mg}$ of heart in WILDER \& SMITH's saline buffered with bicarbonate were put against $0.1 \mathrm{mg}$ acetylcholine. The heart tissue was obtained by severing the allary muscles under the binocular with an iridectomic scissor at their insertion points. In no case decomposition of acetylcholine could be detected.

\section{DISCUSSION}

a. Althcugh it was not the purpose of this work the study of the action of ions on the water bug's heart, some preliminary ccnclusions can be drawn from the results obtained with W/LDER AND SMITH's and YEAGER's salines. These salines differ (see table $\mathrm{I}$ ) significantly in $\mathrm{Na} / \mathrm{K}$ and $(\mathrm{Na}+\mathrm{K}) / \mathrm{Ca}$ ratios and in the fact that the latter has $\mathrm{MgCl} 2$ whereas the former has not. YEAGER s saline arrested immediately the heart of both Belostoma and. Lethoceros. In DAVENPORT's experiment (1. c.), neither LEVY's, nor MALOEUF's, nor YEAGER AND HAGER's (1934 apud DAVENPORT 1. c., p. 23 ) saline, which I presume has a composition similar to that used by YEAGER AND GAHAN (1937) were able to maintain the heart beat of Stenopsimatus. Frog saline, which except for the presence of bicarbonate, is qualitatively and quantitatively similar to WILDER AND SMITH's saline (also a modified Ringer Solution) was then successfully used.

Table I

$\mathrm{NaCl}$, $\mathrm{ZCl}$ and $\mathrm{CaCl}_{2}$ contents of some salines used in insect heart studies.

gin $\mathrm{NaCl} \mathrm{KCl} \mathrm{CaCl}_{2}$ water $\mathrm{Na} / \mathrm{K}(\mathrm{Na}+\mathrm{K}) / \mathrm{Ca}$

$\begin{array}{lrrrcrr}\text { Levy 1928 } & 9.00 & 0.70 & 0.46 & 11 . & 12.8 & 47.0 \\ \text { Maloeuf 1935 } & 9.00 & 0.20 & 0.20 & 11 . & \mathbf{1 5 . 0} & 47.5 \\ \text { Yeager \& Gahan 1937 } & 9.82 & 0.77 & 0.50 & \text { up to 11. } & 7.0 & \mathbf{1 4 . 7} \\ \text { Wilder \& Smith } 1938 & 5.00 & 0.14 & 0.12 & \text { up to 11. } & 33.9 & \mathbf{4 7 . 0} \\ \text { Yeager 1939 } & 10.93 & \mathbf{1 . 5 7} & 0.85 & \text { up to 11. } & 12.6 & \mathbf{2 1 . 2} \\ \text { Davenport 1949 } & 6.70 & \mathbf{0 . 1 5} & 0.12 & \text { up to 1 1. } & \mathbf{4 4 . 7} & \mathbf{4 5 . 7}\end{array}$

The effects of $\mathrm{Na}, \mathrm{K}$ and $\mathrm{Ca}$ on the insect heart were studied by BERGERARD (1947) in Grylius and DREUX (1950) in Galleria. Solutions with $\mathrm{Na} / \mathrm{K}$ ratios less than 8 stop the heart in. 
systole. Higher ratios insrease the rate of beat but decrease the amplitude. Solution with $(\mathrm{Na}+\mathrm{K}) / \mathrm{Ca}$ ratios of less than 3 cause diastolic arrest, higher ratios retard the rhythm and decrease the amplitude. As to magnesium, FISZER (1950 a and b) reported that when it replaces calcium in a perfusing saline the heart of Gryllus is arrested in diastole, but that there is neither synergism nor antagonism between these two ions. Rather, their actions are distinct. There is, however, antagonism ketween magnesium and potassium. Magnesium is found in insect hemolymph in higher concentration than in man and often (LEVENBOOK 1950 in Gastrcphilus, FLORKIN 1943 apud BUCK 1953 p. 160 in Hydrcphilus and BIALASZEWICZ \& LANDAU 1938 apud Buck, 1. c., p. 160 in Bombyx) in strikingly high concentration. FLORKIN (1949) pointed out that $\mathrm{Mg}$ is much higher in proportion to the other cations than in most other animals except marine invertebrates and METCALF (1935) suggested that it derives mainly from chlorophyll. The concentration of magnesium in the blood of insect is high enough to induce anesthesia in most non-marine animals. LEVENBOOK (1949 apud BUCK, 1. c., p. 160) injected magnesium into the body of adult Locusta in a concentration approximating that already present in the blood. Notwithstanding, it rapidly produced a cataleptic condition. After subsequent injection of calcium, which is known to abolish magnesium anesthesia in other animals, the insects recovered quickly. Injection of calcium alone, however, was fatal. LEVENBOOK tentatively concluded that free magnesium as well as free calcium are toxic and that probably they do not occur as such in the insect blood, but bcund to protein. On the basis of these results, the failure of LEVY's, of YEAGER \& HAGER's salines in maintaining the heart beat of Stenopelmatus might be explained on account of relatively low $\mathrm{Na} / \mathrm{K}$ ratios and perhaps excessively high concentrations of $\mathrm{NaCl}, \mathrm{KCl}$ and $\mathrm{CaCl}_{2}$ as compared with WILDER AND SMITH's or frog saline (KOZHANTOCHIKOV 1932 apud BEARD, 1. C., p. 269 obtained in Blatta a systolic standstill with hypertonic Ringer solutions). The failure of YEAGER's saline, on the other hand, in maintaining the heart beat in the water bug can be attributed to the presence of $\mathrm{Mg}$ ions, and the low $\mathrm{Na} / \mathrm{K}$ ratio. 
The fact that the optimal $\mathrm{pH}$ for the water bug heart seems to be on the acid side of the neutral point can not be considered as astonishing, since it is well known that eight five per cent of the values for the hydrogen-ion concentration of insect blood fall slightly on the acid side of neutrality (BUCK 1953).

b. The responses of both Belostoma and Lethoceros hearts to adrenalin reveal that the organ is sensitive to the drug. Adrenalin can stimulate the heart beat $\left(10-^{7}\right.$ and $\left.10^{-6}\right)$ or even induce a systolic tetany $\left(10^{5}\right.$ and $\left.10-^{4}\right)$. These results agree with those obtained by KRIJGSMANN \& KRIJGSMANN (1. c.) on the isolated heart of Periplaneta where stimulation was also obtained with adrenalin. They are not in agreement with those of DAVENPORT (1. c.) reported for another Orthopteran, Stenopelmatus, namely, that the drug at $10-{ }^{6}$ retards and at higher concentrations arrests the heart in diastole.

c. From the results obtained when $100^{6}$ up to $10-^{3}$ acetylcholine solutions were pipetted upon the water bug heart, it seems that little or even nothing can be said in favor of any particular action of the drug. These results are in complete disagreement with the those of previous authors, which all found stimulatory effects of acetylcholine, as already mentioned. The question naturally arises: Are these differences in effect caused by differences in intrinsic nervous mechanisms of the animals studied? ALEXANDROWICZ (1926) reported the presence of ganglionic cells in the lateral heart nerves of Blatta. DAVENPORT (1. c.) found in Stenopelmatus ganglia and nerves closely invested to the heart muscle by the surrounding connective tissue. As to Melanoplus, Apis and Periplaneta in which HAMILTON (1. c.), PROSSER (1. c.) and KRIJGSMANN \& KRIJGSMANN (1. c.) respectively found stimulatory effects of acetylcholine, no reference is made in their papers to the presence or absence of ganglia in the heart. From experiment with the water bug Belostoma flumineum MALOEUF (1. c.) suggested that in this Hemipteran the heart beat and rhythm are probably independent of posible rhythmic impulses dispatched from ganglionic cells. May be this is also the case in the water bugs used in the present work and that would explain the results 
obtained with acetylcholine since according to PROSSER (1. c.) hearts unaffected by this drug are noninnervated.

d. No cholinesterase activity could be detected in extracts of the heart of both Belostoma and Lethoceros, using the AMMON (1. c.) technique. HAMILTON, using the responses of the frog and turtle hearts to the grasshopper brei also could not detect cholinesterase in this Orthopteran. However, using the Cartesian Diver technique, MEANS (1942) demonstrated that the grasshopper heart extracts has a small (as compared with the nervous and muscular estructures) QCH.E of 0.40. HAMILTON (1. c.) recognized that the absence of cholinesterase in Melanoplus rendered difficult a natural function of acetylcholine in that animal's nervous system and, although he obtained acceleration of the heart beat with acetylcholine, he states that "it seems very improbable that it could be of importance in the nerve conduction of this insect", since, among other things, the intact grasshopper is relatively insensitive to acetylcholine. On the basis of the results of MEANS (1. c.), however, and from his own results with physostigmine, DAVENPORT (1. c.) suggested that the heart action in insects might represent a cholinergic system. Although complementary studies are still necessary, the present evidence in the case of the water bug does not seem to support this view.

\section{SUMMARY}

1. The action of acetylcholine and adrenalin on the heart of two aquatic Hemipterans (Belostoma and Lethoceros) was studied.

2. Preliminary tests in order to find out the suitable physiological saline for the experiments indicated that WILDER \& SMITH' saline, with $\mathrm{Na} / \mathrm{K}$ and (NA $+\mathrm{K}$ )/Ca ratios similar to those of frog saline used by DAVENPORT in his insect heart studies, was to be adopted. YEAGER's saline which contains $\mathrm{Mg} \mathrm{Cl} \mathrm{Cl}_{2}$ stopped the heart of the water bug. A brief discussion of the action of ions on the heart action is given. The fact that the water bug heart beat was better maintained in unbuffered saline ( $\mathrm{pH}$ ca.5.5) than in saline adjusted to $\mathrm{pH}: 7.3$ with a buffer, 
suggests that the $\mathrm{pH}$ optimal for the heart action in these insects seems to be on the acid side of the neutral point.

3. The heart beat was recorded in situ in the case of the large Lethoceros and checked visually with a stopwatch in the case of smaller Belostoma. The average heart rate in the former was 24 beats per minute and in the latter 36 , at ca. $20^{\circ} \mathrm{C}$.

4. Adrenalin acts upon the water bug heart, increasing the frequency in concentrations equal to $10-^{7}$ and $10^{6}$. At $10^{-5}$ it induces a systolic tetany, which can be almost complete with 10-4.

5. Acetylcholin produced no modifications on the heart beat of the water bug when used in concentrations from $10^{6}$ up to 10- ${ }^{3}$. When $10-^{2}$ ACh was tested an immediate diastolic block was observed.

6. No cholinesterase activity was detected when, using the AMMON technique, heart extracts of Belostoma and Lethoceros were put against acetylcholine solutions.

7. From the lack of action of acetylcholine, from the absence of cholinesterase activity of heart extracts and from the fact that probably in the water bug the heart and rhythm are independent of possible rhythmic impulses from ganglionic cells (MALOEUF in Belostoma flumineum) it is here suggested that at least in the Hemipterans studied the heart action does not seem to represent a cholinergic system.

\section{SUMÁRIO}

1. Foi estudada a ação da acetilcolina e da adrenalina sôbre o coração de dois insetos hemipteros aquáticos (Belostoma e Lethoceros), conhecidos por baratas d'gua.

2. Provas preliminares a fim de encontrar o líquido fisiológico mais apropriado para as experiências indicaram que a solução de WILDER e SMITH, cujas relações $\mathbf{N A} / \mathrm{K}$ e $(\mathrm{Na}+\mathrm{K}) / \mathrm{Ca}$ são semelhantes às do Ringer de Anfíbio usado por DAVENPORT nos seus estudos sôbre o coração dos insetos, era de se adotar. A soluçāo de YEAGER, que contém $\mathrm{MgCl}_{2}$, parou o coração da barata d'água. $O$ fato do coração dêstes insetos se manter 
melhor em solução fisiológica não tamponada ( $\mathrm{pH}$ ca. 5.5) do que na de $\mathrm{pH}$ ajustado com tampão a 7.3 sugere que o $\mathrm{pH}$ ótimo para a atividade cardíaca parece estar no lado ácido do ponto neutro.

3. O batimento cardíaco foi registrado in situ no caso dos grandes exempiares de Lethoceros e contados com um cronômetro no caso dos espécimes menores de Belostoma. A taxa cardíaca média nos primeiros foi de 24 batimentos por minuto e nos segundos de 36 , a $20^{\circ} \mathrm{C}$.

4. Adrenalina age sôbre o coração da barata d'água aumentando a freqüência, quando em concentrações de $10-^{7}$ e $10^{6}$. A $10-{ }^{-}$induz tetanía sistólica, que se torna quase completa a $10-^{4}$.

5. Acetilcolina não produziu modificações no batimento cardíaco da barata d'água quando usada em concentrações de 10- ${ }^{6}$ até $10^{-3}$. Quando $10^{2}$ foi experimentada o coração parou imediatamente em diástole.

6. Não se registrou atividade colinesterásica quando, usando-se a técnica de AMMON, coloc'aram-se extratos do coração de Belostoma e Lethoceros em contacto com soluções de acetilcolina.

7. Com base na falta de atividade da acetilcolina, na ausência de poder colinesterásico de extratos de coração de barata d'água e finalmente no fato de que provàvelmente nesses hemipteros o batimento e o ritmo cardíaco independem de impulsos ritmicos advindos de células ganglionares (MALOEUF in Belostoma flumintneum), sugere-se aqui que, pelo menos no caso dos hemipteros estudados, a atividade cardḱaca não represente um sistema. colinérgico.

\section{LITERATURE}

ALEXANDROWICZ, J. S. 1926 - The innervation of the heart of the cockroach (Periplaneta americana). J. Comp. Neurol., v. 41, pp. 291-309. AMMON, R. 1934 - Die Fermentative Spaltung des Acetylcholins. Arch. f. d. ges. Phys., v. 233, pp. 486-491. BEARD, R. L. 1953 - Circulation, in K. D. Roeder's Insect Physiology XIV + 1100 pp. New York \& London, pp. 232-272. BERGERARD, J. 1947 - Influence des ions $\mathrm{K}$ et Ca sur l'automatisme du vaisseau dorsal de Gryllus domesticus L. C. R. Soc. Biol. Paris, v. 141, pp. 1079-1081. BUCK, 
J. B. 1953 - Physical Properties and Chemical composition of Insect blood, in Roeder's Insect Physiology, XIV + 1100 pp. New York and London, pp. 147-190. DAVENPORT, D. 1949 - Studies in the pharmacology of the heart of the Orthopteron, Stenopelmatus. Phys. Zool., v. 22, pp. 35-44. DREUX, P. 1950 - Influence des ions $\mathrm{K}$ et Ca sur l'automatisme du vaisseau dorsal de la chenille de Gallería mellonella L. C. R. Soc. Biol. Paris, v. 144, pp. 803-804. FISZER, J. 1950a Action de l'ion $\mathrm{Mg}$ sur l'automatisme du vaisseau dorsal de Gryllus domesticus L. C. R. Soc. Biol. Paris, v. 144, pp. 812-814. - 1950b - Actions antagonistes du magnésium e des ions alcalins sur l'automatisme du vaisseau dorsal de Gryllus domesticus L. C. R. Soc. Biol. Paris, v. 144, pp. 815-817. FLORKIN, M. 1950 - Biochemical Evolution VI $+157 \mathrm{pp}$. New York, Academic Press. HAMILTON, H. L. 1939 - The action of acetylcholine, atropine and nicotine on the heart of the grasshopper (Melanoplus differentialis) J. Cell and Comp. Phys., v. 13, pp. 91-103. - KRIJGSMANN, B. J. and N. E. KRIJGSMANN 1950 - Heart mechanism of Arthropods. Nature, v. 165, pp. 936-940. LEVENBOOK, L. 1950 - The composition of Horse Bot Fly (Gastrophilus intestinalis) larva blood. Bioch. Journ., v. 47, pp. 336346. LEVY, R. 1928 - Fonctionnement du vaisseau dorsal de la larve de mouche en millieu artificiel. C. R. Soc. Biol. Paris, v. 99, pp. 1482-1485. MALOEUF, N. S. R. 1935 - The myogenic automatism of the contraction of the heart of insects. Ann. Ent. Soc. America, v. 28, pp. 332-337. MEANS, O. 1942 - Cholinesterase activity of tissues of adult Melanoplus differentialis (Orthoptera, Acrididae). J. Cell and Comp. Phys., v. 20, pp. 319-324. METGALF, R. L. 1945. A study of the metabolism of chlorophyll in the squash bug Anasa tristis De Geer. Ann. Ent. Soc. Amer., v. 38, pp. 397-402. PROSSER, C. L. 1942 - An analysis of the action of acetylcholine on hearts, particularly in Arthropods. Biol. Bull., v. 83, pp. 145-164. WILDER, J. and C. SMITH 1938 - The Malpighian tubules in the adult Melanotus communis Gyll. Ann. Entom. Soc. America, v. 31, pp. 61-66. YEAGER, J. F. 1939 - Electrical stimulation of isolated heart preparations from Periplaneta americana. Journ. Agr. Res., v. 59, pp. 121-137. YEAGER, J. F. and J. B. GAHAN 1937 - Effects of the alkaloid nicotine on the rhythmicity of isolated heart preparations from Periplaneta americana and Prodenia eridania. Journ. Agr. Res., v. 55, pp. 1-19. 